\title{
Exponential Atlases: A Metaphysical Approach to the Organizational Rapid Growth
}

\author{
Leonardo Pompa ${ }^{1}$ \\ ${ }^{1}$ Department of Communication and Economics, University of Modena and Reggio Emilia, Italy \\ Correspondence: Palazzo Dossetti, viale Antonio Allegri, 9, 42121 Reggio Emilia, Italy. E-mail: \\ leonardo.pompa@unimore.it
}

Received: February 3, 2019

Accepted: February 28, 2019

Online Published: March 8, 2019

doi:10.5539/ijbm.v14n4p143

URL: https://doi.org/10.5539/ijbm.v14n4p143

\begin{abstract}
According to Greek mythology, Atlas held up the sky on his shoulders. Nowadays, the term atlas refers to "a book of maps or charts" (1). In this paper, the term is used in both senses. On the one hand, the purpose is to understand the conditions favoring - hold up - the birth and the evolution of exponential organizations. On the other hand, the goal is to draw a concept map that allows us to identify the interactional dynamics among the actors involved in this evaluative process. In other words, first I'll try to know who "holds up the sky" (static interpretation), and then we will see who "lives in it" (moving interpretation). The idea is that disruptive innovation mediates the relationship between environmental/organizational features (conditions) and exponential growth (phenomenon). So far, little consideration has been given to the favorable conditions that can allow organizations to become exponential. This paper aims to pave the way for future systematized research on the ExO's genesis and development.
\end{abstract}

Keywords: organizational growth, disruptive innovation, theoretical approach

\section{Introduction}

\subsection{Exponential Organization: Definition and Its Relevance in the Current Socio-Economic Context}

The theme of exponential organizations (ExOs) has emerged in recent years, mainly thanks to the work of Salim Ismail (2013) and his colleagues at Singularity University (2). From his point of view, "An exponential organization $(\mathrm{ExO})$ is one whose impact (or output) is disproportionally large - at least 10x larger - compared to its peers because of the use of new organizational techniques that leverage accelerating technologies".

The idea of an organization that grows exponentially was inspired by Kurzweil's Law of Accelerating Returns, which is well explained in the homonymous essay of 2001. In this work, Kurzweil points out that technological change is exponential and not linear, as we normally would think. He forecasts that "we won't experience 100 years of progress in the $21^{\text {st }}$ century - it will be more like 20,000 years of progress". Since technology is growing rapidly (Hauer, 2018), organizations must adapt to this new situation and manage it just as quickly (Cao et al., 2018, Kahn, 2018). Therefore, explaining an ExO's success is not sufficient to observe technological growth dynamics, but is necessary to focus on the features an organization must have to become exponential.

Organizational success is mainly based on information technologies (Yunis et al., 2018; Zhang \& Li, 2018; Iacovone et al., 2017; Bourke \& Crowley, 2015) and innovative organizational models (Gronum et al., 2016; Spieth et al., 2016; Philipson, 2016). However, as we will see, other elements, together with these, make exponential growth possible. We are in the age of digitalization (Ianos \& Oproiu, 2018; Jansen \& Jeschke, 2018) and dematerialization (Mykolayivna \& Sergiyovych, 2015; Kallis, 2017), two phenomena that significantly affect our society and our way of life. These phenomena have dramatically changed the way we buy products and services as well as the way we live our relationships; the way we work; and, ultimately, the way we build our future. Until a little over a decade ago, it was almost impossible to imagine giving up many of the physical experiences we normally had. We don't need to physically move to go to the bank, to visit a friend or a museum, or to shopping. This is the era of immateriality. Today's most successful companies are those that manage such immateriality or that offer access to it. In this scenario, understanding the Internet's relevance is easy.

For this reason, an accurate analysis of the ExO conditions cannot ignore the importance of public investments in technological infrastructures. Regarding these issues, Mariana Mazzucato (2013) provides convincing evidence 
of how crucial State support is for the success of many recently founded startups that are now among the largest companies in the world. The changes in the current socio-economic context are manifold, involving consumers' tastes (Sinitsyn, 2018), the way companies do business, and the labor market. According to Ismail (2013), "For any ExO, having Staff on Demand is a necessary characteristic for speed, functionality and flexibility in a fast-changing world. Leveraging personnel outside the base organization is key to creating and running a successful ExO". If this observation is correct, then we must try to imagine how the labor market will change (Rahman, 2017) in the coming years and the consequences. This change will probably force us to rethink the entire higher education system, which must be consistent with the new demand for labor. The ExOs, with their extensive use of accelerating technologies, highlight the new challenges in Human Resource Management. Undoubtedly, the speed of technological change highlights the issue of skill obsolescence, which could be one of the main causes of unemployment in the near future. More precisely, skill obsolescence is the degree to which professionals lack the up-to-date knowledge or skills necessary to maintain effective performance in their current or future work roles (Kaufman, 1974). Although this phenomenon has been analyzed for many years, only now it is manifested with its wealth of implications, especially among older workers (Allen \& de Grip, 2012). According to some researchers, there is no significant correlation between an employee's age and performance, but employees' competencies are important for performance (Güttel et al., 2009).

\section{A general Approach}

What are the external and internal conditions, whose presence and mutual interaction enables an organization to grow exponentially? What kinds of mediating variables are involved in this process? In order to answer these questions, we need to clarify some of the terminology. The terms external and internal refer to an organization. In this respect, external conditions are "environmental conditions" and internal conditions are "organizational capabilities".

This paper is proposing a twofold interpretation of the ExOs. The first is a static interpretation, in the sense that constituent elements of the scenario where the ExOs can grow are examined. In contrast, the second is a moving interpretation, which focuses on how the scenario elements can influence each other.

These two proposed interpretations are not mutually exclusive, but rather are two essential elements of the same theoretical framework. In this work, the ExOs are not considered direct results of the scenario conditions, but rather as possible outcomes of a disruptive innovation widely adopted. This view doesn't imply that the environmental and organizational conditions play a secondary role; if anything, the opposite is true. It is not enough to state that ExOs find most of their lifeblood in disruptive innovations; it must be stressed that disruptive innovations result from a process, which is possible thanks to the presence of specific conditions. My general approach to the ExO phenomenon is inspired by Aristotle's Metaphysics ( $4^{\text {th }}$ Century BC) in which the Greek philosopher discusses the concepts of potentiality and actuality. From Aristotle's point of view, potentiality is a thing's capacity to be in a different and more completed state, whereas actuality is anything currently happening. Consistent with these conceptualizations, Aristotle states that actuality is always prior to potentiality. In our case, the actuality is represented by the scenario conditions, within which can stem two potentialities: disruptive or not-disruptive innovation. At a later stage, these potentialities may generate a new actuality: an ExO.

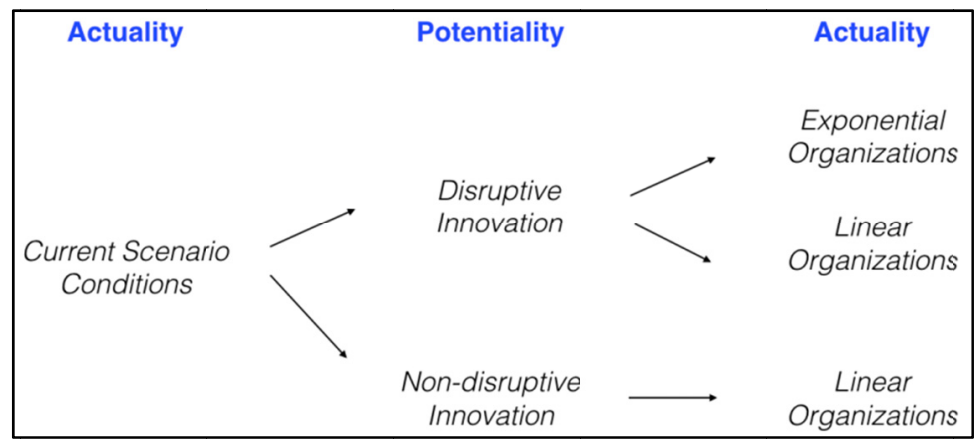

Figure 1. A general approach: ExO Resulting from an "Actuality-Potentiality” Process

Figure 1 summarizes the two interpretations that will be discussed. More specifically, the static and moving interpretations emphasize, firstly, the distinctive aspects of a context favorable to ExOs and, secondly, the way in which we can move from the possibility of an exponential outcome to its concrete realization. To better 
understand these two phases, see Figure 2.

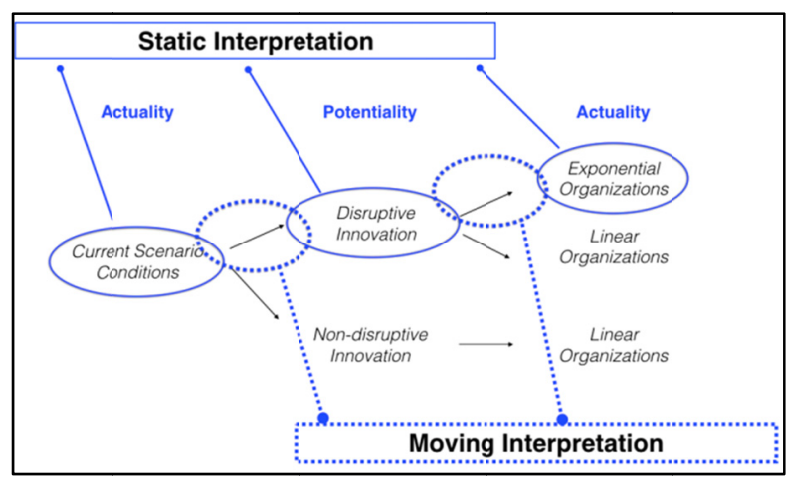

Figure 2. Theoretical Framework for Interpreting an ExO's Genesis

\section{$2.11^{\text {st }}$ Interpretation: A Static Atlas}

In this section, we will seek to understand the scenario conditions related to disruptive innovation. Literature on the scenario conditions and on disruptive innovation will be reviewed. Then these different contributions will be used to construct an interpretative framework for the present ExOs analysis. This type of interpretation allows us to identify swiftly some of the most important conditions from which disruptive innovations and, indirectly, an $\mathrm{ExO}$, may stem. As shown in Figure 2, the static interpretation highlights three elements: scenario conditions, disruptive innovation, and exponential organizations.

Before becoming exponential, an organization acts in a particular environment (external conditions) and has certain characteristics (internal conditions). In this work, I consider the scenario conditions as the sum of the external and internal conditions. Figure 3 is an overview of the static interpretation.

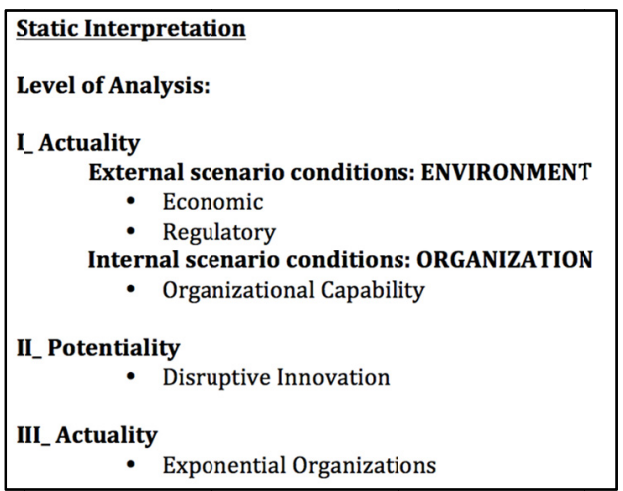

Figure 3. Exponential organization conditions: a static atlas

\subsubsection{External Scenario Conditions}

For many years, researchers have tried to determine the best way to study the economic environment in which organizations act. Many studies focusing on this topic take for granted that the environment evolves in a predictable way or, in any case, at a rate not too high. Eisenhardt and Martin (2000) state that even in markets where changes are frequent, the evolutionary paths can be relatively stable and linear. Although this observation may be true in traditional contexts, it is difficult to imagine predictable evolutionary paths in a scenario strongly affected by accelerating technologies. I consider external scenario conditions the economic and regulatory environments.

The economic environment can be seen from many points of view; moreover, innumerable aspects can be considered. In general, within a given economic environment, the presence of any kind of disruptive innovation is more likely if that context contains two elements: 


\section{1) public support university $R \& D$}

\section{2) technological infrastructures.}

Since these elements are made available largely by the State, the relationship between economic environment and disruptive innovation can be interpreted by highlighting public investments' role in innovation. For example, public basic research's importance has been emphasized in the pharmaceutical industry, where there is no shortage of evidence about the relationship between academic research and industry innovation (Toole, 2012). According to Salter and Martin (2001), there are three main methodological approaches to publicly funded scientific research's benefits: econometric studies, surveys and case studies. These researchers maintain that each of these methods has limitations; therefore, measuring academic research's economic impact remains problematic. Nevertheless, we can understand public research's role by observing collaboration between academia and industry. The State, indeed, not only supports university R\&D, but also offers funding for university-industry collaborative research (Berman, 1990). Thus, public intervention's importance in highly innovative contexts is undeniable. This kind of support's impact is felt in a great variety of private industry performance outcomes: industry and economy-wide economic performance, new drugs, formation of new companies, direct increases in employment, increased stock of useful knowledge, and skilled engineers' and scientists' training (McMillan \& Hamilton III, 2003). We could say that the State's presence is important for two main reasons: creation and diffusion of innovation. If public-supported university R\&D is important for the creation process, the diffusion process cannot do without public infrastructures. This second aspect of the external scenario grabs scholars' attention in different ways. According to Bivens (2012), "public investment by federal, state, and local governments builds the nation's capital stock by devoting resources to the basic physical infrastructure, innovative activity (basic research), green investments, and education". Public infrastructures are critical to firms' performance and, more generally, to economic growth (Morrison \& Schwartz, 1996). The public sector is present at every stage of the innovation chain, from basic research to commercialization (Salandra, 2018; Liang \& Liu, 2018) and its spending favors the emergence of new markets and sectors, including the Internet (Mazzucato, 2015). The most obvious proof that public investments are crucial for this kind of organization is the fact that most ExOs could not operate without the Internet.

The economic environment is not the only source of the disruptive innovation. The regulatory environment must also be considered. Different types of regulations can influence innovation in various ways (Blind, 2012). Generally, in the literature, three types of regulations are discussed: economic, social and institutional. In this study, I consider more relevant the first one. From the viewpoint of economic regulation's impact on innovation, one of the most important issues is competition regulation policies. The basic rule emerging from the extensive empirical evidence is that competition increases organizations' incentives to innovate, but only up to a point. When the competition gets too intense, companies prefer to imitate rather than innovate (Aghion et al., 2005). The Uber case is helpful in identifying the relationship among regulation, disruptive innovation, and ExOs. Indeed, Uber's presence disrupted the traditional taxi services scenario. In some countries, this ExO's growth has been facilitated by a favorable - or, at least, non-hostile - regulation system. In contrast, in other nations, Uber continues to face many obstacles, represented by regulatory systems protecting the traditional market balances. According to Larry Downes (2013), this is proof that "innovation and regulation don't mix."

\subsubsection{Internal Scenario Conditions}

To understand the ExO's emergence is not enough to focus on what happens in the external environment. It is also important consider the organization's contribution to its growth. In general, a firm can purchase or develop a disruptive innovation or an innovation that could be disruptive. In both cases (purchasing or developing), the organizational capability is important. Organizational capability could be defined as the "ability and capacity of an organization expressed in terms of its human resources, physical and material resources, financial resources, information resources and intellectual resources."(3). This myriad of meanings reveals the complexity of the internal scenario conditions. Capabilities are important because they allow us to fill the gap between our intentions and the outcomes we are able to achieve (Dosi et al., 2001). In his 1994 paper, Collis recognizes three categories of organizational capabilities. The first category is the ability to perform a firm's basic functional activities; the second category is the capacity to create dynamic improvement in a firm's activities; the third category is the firm's ability to develop novel strategies before competitors do (Collis, 1994). In other words, organizational capability is the sum of the things that the organization knows. This definition is perfectly consistent with the idea that organizational capability is the result of an "integration of knowledge" (Grant, 1996). This concept is undoubtedly effective, but alone is not enough to represent the complexity of the concept that I'm trying to highlight. Thus, it may be useful to interpret organizational capability as the set of resources that an organization has accumulated over time (Lun et al., 2016) and that, in a given moment, can be used to achieve a 
competitive advantage. In the present work, the organizational capability represents the following: financial capabilities, physical resources, information resources, HR capabilities, marketing capabilities, structure, culture, strategy, R\&D, and any other element the organizational actions are based.

\subsubsection{Disruptive Innovation}

The adjective disruptive has acquired great relevance in managerial literature through the contribution of such authors as Bower and Christensen. In their 1995 paper, they focused on disruptive technology and its impacts on markets and on organizational processes. According to Bower and Christensen, innovations are not all equal because of a substantial difference regarding the impact that an innovation might have on a given industry. Depending on the type of impact, an innovation can be sustaining or disruptive. A sustaining innovation is one that helps improve some aspects of a product or service that the customers already know and value. In contrast, a disruptive technology offers a very different experience that initially is found only in a new market (Bower \& Christensen, 1995). Over the years, many scholars have dealt with the relationship between disruptive technologies and competition (Adner, 2002; Huang \& Sošić, 2010), referring to the idea that in the early stages, a disruptive innovation is inferior to traditional technology but is appreciated by a niche market (Christensen, 1997). This niche, a bit at a time, expands until it reaches the most consumers in the market. To explain this phenomenon, Christensen (1997) uses the concept of performance oversupply, which states that when the market's needs are met, the consumers' attention begins to focus on the product's features that were initially considered unimportant. While acknowledging the importance of his work, some researchers believe that Christensen has left many questions unanswered (Adner, 2002; Danneels, 2004; King \& Baatartogtokh, 2015). The terminology used within the disruptive innovation theory is judged inconsistent (Chesbrough, 2001). In this regard, the following is one of the questions researchers believe Christensen did not answer: "What are the exact criteria for identifying a disruptive technology?" (Danneels, 2004). The open issue is whether it is possible to create a framework to predict ex ante the emergence of a disruptive innovation (Doering \& Parayre, 2000; Lepore, 2014). To dispel all doubts, analyzing many practical cases would be useful because the validity and generalizability of Christensen's theory have seldom been tested in the managerial literature (King \& Baatartogtokh, 2015). In order to fill this lacuna, the best solution would be to follow the approach of those who integrate the Christensen's model with appropriate analyses from its critics (Govindarajan \& Kopalle, 2006), considering that the expression disruptive innovation refers to not only technological products, but also business models (Christensen \& Raynor, 2003; Chang \& Hang, 2010). Combining these different approaches, we can synthesize the main characteristics of a disruptive innovation (DI):

1) underperforms, at early stages, on the attributes that mainstream customers value;

2) offers something new to attract price-sensitive customers;

3) moves from niche to mainstream market.

Having said this, we must consider that disruptive innovation doesn't always imply that an emerging business will replace incumbents (Yu \& Hang, 2010). The three salient features just mentioned are found in the history of Waze, an ExO. At the beginning of its activity, the novelty Waze introduced was a new navigation system, which was based on sharing location information. This system's construction was made possible by leveraging the GPS sensors installed on the Waze users' phones (Ismail, 2013). At that time (2007), this innovation was inferior compared to the services Nokia offered because smartphone diffusion was still too low (first charactersitic). At a later stage, the smartphones' rapid spread and the fact that the app was free (second characteristic) led to an increased number of users. The mainstream market was quickly disrupted and Waze, derived from a niche market (third characteristic), replaced Nokia.

\subsubsection{Exponential Organizations}

The managerial literature has not showed great interest in the ExO. In fact, the only work in which this issue has been debated in a very structured way is Exponential Organizations, Salim Ismail's 2013 book. In this book, Ismail defines exponential organization (ExO) as "one whose impact (or output) is disproportionally large - at least 10X larger - compared to its peers because of the use of new organizational techniques that leverage accelerating technologies". Ismail clarifies that an ExO is not built on "armies of people or large physical plants" but on information technologies. In this respect, ExOs result from a digital data's general tendency spread. The main reason focusing on this kind of organizations is important is that ExOs are different from other organizations in many ways. These differences are manifested at different levels: strategy, structure, culture, processes, operations, systems, people and key performance indicators (Ismail, 2013). 


\subsection{2nd Interpretation: A Moving Atlas}

Up to this point, we have seen elements of our analysis isolated from each other. This kind of approach has allowed us to clarify from what point of view we are observing each construct. Now, we will try to understand how these elements are bound together. In addition, I introduce a new element, the rate of early adopters, which represents the fifth link we will see. Figure 4 is a synthetic representation of the "moving atlas."

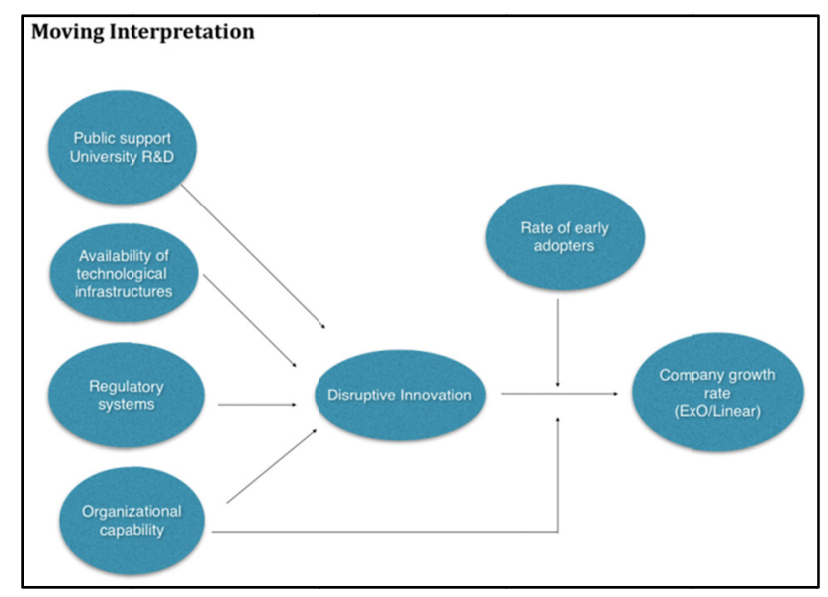

Figure 4. A Moving Interpretation of the ExO

Each of the four conditions represented here plays a crucial role in the emergence of disruptive innovation. We are going to observe each of them in order to understand that the presence of at least one of these links is essential for innovation.

First link (publicly support university $R \& D$-disruptive innovation-ExO). Very often we are unable to understand the link between basic research and innovation. Furthermore, seeing the relationship between basic research and socio-economic well-being is difficult. One of the causes of this situation is the fact that basic research results are non-patentable, so while one firm cannot easily capture basis research's benefits, the government benefits if new insights ripple across the economy (Markovich, 2012). According to Markovich, the federal government is the primary funder for basic research in the United States. In this scenario, the presence of top colleges and universities is outstanding. In recent decades, it has increased the share of gross domestic product (GDP) devoted to basic and applied research. In the 2015 budget for Science, Technology and Innovation, President Barack Obama has allocated $\$ 64.7$ billion for federal research, up \$251 million compared to the 2014 enacted level (4).

The link between publicly funded research (academia) and the innovation coming from firms (industry) can be seen in the Etzkowitz's Triple Helix Model (Etzkowitz 1993; Etzkowitz \& Leydesdorff, 1995). In their 1995 paper, Etzkowitz and Leydesdorff discuss a new social contract between a university and the larger society, overcoming the old idea of only long-term contributions of academic knowledge to the economy. In the same paper, they state that the linear models of "demand pull" or "technology push" have lbeen superceded by an evolutionary model that analyzes economic development in terms of networks. Therefore, science-based socio-economic well-being may stem only from a "triple helix" of academic-industry-government relations. Emblematic of this kind of relationship is the way in which academic research assisted the manufacturing industry in Boston, as reported by Etzkowitz (1993). The presence of public science in innovation processes is felt in many areas, such as biotechnology, which represents an industry that is knowledge-based and predominantly composed of small firms with close ties to university scientists (Audretsch \& Stephan, 1996; McMillan et al., 2000). According to some studies, the main reason the government supports academic research is not only science's economic impact (Narin et al., 1997); historically, the Western economies' growth has depended on nations' capability to absorb and utilize scientific knowledge (Rosenberg \& Birdzell, 1990).

The success of many fast-growing companies comes from the academic knowledge of those who developed the innovation at the base of the firms' core business. For example, electric cars probably wouldn't exist without lithium-ion batteries. At the same time, would the lithium-ion batteries exist without academia? To answer this question, we must understand who was behind this innovation. Lithium-ion batteries' invention and success are mainly associated with two innovators: Whittingham and Goodenough. Whittingham was educated at Stamford 
School in Lincolnshire, Oxford, and Stanford. With his Stanford's colleagues, Whittingham developed the first lithium-ion battery in the 1970s (Levine, 2015). This invention focused Exxon's attention on Whittingham and opened the way to further improvements of this new discovery. The most important improvement was made by Goodenough, who studied at Yale and Chicago and worked at MIT, Oxford, and the University of Texas. Thanks to Goodenough's discoveries, Sony released the first commercial lithium-ion battery in 1991. The lithium-ion battery (Stephan et al., 2017), as we know it today, is the result of thousands of hours of study and research conducted in classrooms and laboratories. The government and academia have contributed to this innovation's wide diffusion. Without these contributions, we wouldn't have electric cars and Tesla wouldn't be an ExO. In the same way, without lithium-ion batteries, there would be no smartphones; and many of the most famous ExOs whose products and services are spread thanks to these batteries wouldn't exist.

Second link (technological infrastructures-disruptive innovation-ExO). In this section, I use the term technological infrastructures as a synonym for Information and Communication Technology (ICT). According to Van der Meer and Van Winden (2003), ICT must be analyzed from three points of view: access, content and infrastructure.

Access. Access refers to the capability to use information technologies. Globally, one of the most urgent issues to be addressed is the digital divide, which is the inequality between those who can easily use this kind of technology and those who don't have this opportunity. The digital divide refers to both individuals and organizations (Morone 1989, James, 2002; Friedman \& Deek, 2003), and its presence generates a strong impact on the most disadvantaged geographic areas' economic growth, with scarce or no access to ICT. In addition to the digital divide, which describes the gap in access to and use of ICT, another kind of technological inequality is the innovation divide. This second divide describes the gap in technology creation and in ownership of related intellectual property (Drori, 2010). The reasons for these inequalities can be manifold: inability to use an electronic device, lack of income, or absence of electricity or internet infrastructure. As long as these gaps increase, the possibilities for innovation diminish, both for people and organizations. A country that focuses on innovation should first focus on ICT's infrastructure and on access to it. Regarding access, however, another important element is ICT's educational aspect. According to Dìz-Chao and colleagues (2015), ICT improves productivity only when firms and workers achieve the necessary technological competencies.

Content. Van der Meer and Van Winden define content as electronically available information, interactive services, or other content related to a specific locality. Examples of content are local newspapers on the Internet, websites providing traffic situations, and virtual communities. The concept of content has to do with communication. Creating content means to make known outside what happens within a given context. While Van der Meer and Van Winden deal with cities in their paper, we may try to extend the same concept to ExOs. Technological infrastructures are important for organizations (Dragoi \& Dumitrescu, 2014) to highlight and transmit their own "content" in the form of innovations, products, services and future projects. In order to understand the importance of this component of ICT, consider whether an organization could grow exponentially if no electronic information were available about it.

Infrastructure. The importance of public infrastructure investments for economic growth has been widely debated. Some authors have argued that the lack of public spending on infrastructure in the United States has played a great role in explaining productivity's slowdown since World War II (Aschauer, 1988, 1993). In other countries such as Canada, economic prosperity has been based on continually upgrading infrastructures available for goods production and trade (Wylie, 1996). According to Wylie, "goods production does not occur in a vacuum; it is part of the larger economic system that incorporates the basic infrastructure of economic activity" For this reason, innovation and economic growth require resources that go beyond the firms' production components, such as airports, highways, electric power systems, and commercial services. All these types of infrastructure are important, but electronic infrastructures are equally crucial for innovation and growth. Physical manifestations of the ICTs, electronic infrastructures (copper, coax lines, wireless networks, fiber optic lines) represent the information society's transportation system, carrying bits and bytes of information (Van der Meer and Van Winden, 2003). To indicate these infrastructures, some scholars use other terms, such as e-infrastructure or cyberinfrastructure (Edwards et al., 2009). The more a country invests in infrastructure, the more the possibility increases for the companies to innovate and develop new solutions and new products. Consequently, an ExO's emergence is impossible in a context where the government doesn't invest enormous resources for infrastructure. The accelerating technologies that underpin their growth, in fact, cannot express any potential without the presence of physical support.

Third link (regulatory systems-disruptive innovation-ExO). The link among regulations, innovation, and organizational growth is a relatively unpredictable process. In an interesting 2014 article on Ecosystem 
Insights' website, the Endeavor Insight researchers asked, "If business regulations are so important, why is Silicon Valley successful?"(5). Their focus was on two seemingly conflicting reports:

1) PrivCo's "The top 10 cities of the year for private tech acquisitions 2014"(6)

2) U.S. Chamber of Commerce Foundation's "Regulatory Climate Index 2014"(7)

According to the first report, the San Francisco and Silicon Valley area had more than 280 acquisitions in 2013. The value of the companies acquired was $\$ 5.6$ billion. For this reason, this area was at the top of the list. Silicon Valley had four times more acquisitions than New York City (\#2) and ten times more than San Diego (\#3). This finding raises these questions: How important was the California's regulatory system? Did the Silicon Valley reach first position in this ranking as a result of favorable regulations? The second report seems to say no. Indeed, in the Chamber of Commerce Foundation's ranking is a deep analysis of business regulations in U.S. cities based on many indicators, including procedures, time and costs of launching a company, and costs of conducting day-to-day activities. This analysis ranked the Silicon Valley ninth and New York City tenth. In other words, the second report's findings seem the reverse of the first report, thus raising the following questions: What is the truth? How important are the regulations? The Regulatory Climate Index (RCI) is derived from the World Bank's Doing Business (DB) ranking that analyzes the relationship between regulations and business activities since 2004. The DB's aim is to investigate "the scope and manner of regulations that enhance business activity and those that constrain it" (World Bank, 2004). Some scholars argue that countries with better institutions grow faster (Messaoud \& Teheni, 2014), but these findings seem to contradict the results from the survey conducted by the Chamber of Commerce Foundation. According to Davis and Kruse (2007), "assessed solely as research project, the DB project is extremely impressive in terms of the creativity of its design, scale and rigor"; but at same time, they argue that the DB's authors should be clearer in describing some of the analyses used to generate their conclusions. Is this the reason the Silicon Valley's position in the RCI's ranking seems paradoxical? Probably not, but many factors could be considered. If Silicon Valley doesn't stand out for its business friendliness, why have so many ExOs emerged and are emerging there? Either a link between regulations and ExOs does not exist, or the relationship between disruptive innovations and ExOs needs to be examined in depth.

Fourth link (organizational capability-disruptive innovation-ExO). In highly innovative contexts such as the ones within which ExOs operate, organizational capabilities are particularly important. The more unique these capabilities are, the more likely the organization can gain an advantage over competitors (Eshima \& Anderson, 2017; Guo et al., 2014). If we consider organizational capability as the idiosyncratic, difficult-to-copy resources available to the organization, then a resource-based view (RBV) can be very useful in interpreting this fourth link. A RBV (Penrose, 1959; Grant, 1996) helps to explain the importance of being different in turbulent and highly changeable environments. We know that disruptive innovations create a new market. From this point of view, Prahalad and Hamel (1990) were right in saying that "the critical task for management is to create an organization capable of infusing products with irresistible functionality or, better yet, creating products that customers need but have not yet even imagined". An interesting 2012 empirical study shows that the organizational ability to sustain innovation has become critical for sustaining business success and that this ability depends largely on the capability to be responsive to change (Lewrick et al., 2012). In order to generate disruptive innovation, both the ability to be different and the ability to change are important. Similarly, an ExO needs to distinguish itself at the beginning of its growth and to change in later stages when its market begins to transform.

Fifth link (Organizationational capability-rate of early adopters-disruptive innovation-ExO). As shown in Figure 1, a disruptive innovation can lead to the emergence of either a linear or an exponential organization. All four links that we have analyzed up to now could also be applied to organizations that are not exponential. A linear firm, just like an ExO, needs favorable environmental conditions and adequate wealth of organizational capabilities. The real difference between ExOs and linear organizations (LOs) is time. An ExO grows much faster. In other words, the innovation on which an ExO's growth is based spreads at unprecedented speed. ExOs reach the value of a billion dollars in just few years as a result of their innovations' diffusion rate. If we did not consider the time involved, all organizations that reach the value of one billion would be considered exponential. In that case, no difference would exist between ExOs and LOs, and writing about this topic would not make sense. The reason for considering the rate of first adopters is simple: the higher this rate, the higher the likelihood that an organization becomes exponential.

\section{Future Research Horizons and Implications}

Consistently with the "actuality-potentiality" approach represented in Figure 1, an ExO results from a complex process involving many environmental and organizational factors (actuality), without which creating any type 
of innovation (potentiality) is impossible. Innovation is considered potentiality because from it several new possible scenarios can be derived. On the one hand, it can be disruptive or non disruptive; on the other hand, a disruptive innovation is also a potentiality because from it a $\mathrm{LO}$ or an $\mathrm{ExO}$ may stem. Much depends on the way in which the disruptive innovation is managed, valued and adopted. Only one of this potentiality's possible outcomes is represented by ExO (actuality).

The links we have seen are not the secret formula for success. Many other elements contribute to determining an ExO's fate. Nevertheless, if the environment is hostile to disruptive innovation, if the organization is not able to develop or acquire innovation, if the marketing strategies are wrong and the new product or service has a low rate of first adopters, then it is unlikely to give rise to an ExO. From this viewpoint, the links do not show what elements are sufficient, but rather show what elements are necessary for exponential growth.

This research domain's future is yet to be written. We have many horizons to explore. I will examine four.

First Horizon (new extended atlases). One of the possible directions in which future research might be aimed is linked to this simple question: What other conditions are associated with the emergence of ExOs? In other words, we could extend the static and moving interpretations, incorporating elements that are not taken into account here. The new expanded atlases would contain much more information and would describe more accurately this kind of organization.

Second Horizon (quantitative atlases). Starting from the theoretical framework proposed here, we can proceed to collecting, processing, and interpreting data in order to test empirically some concrette hypotheses. This test would allow us to measure the strengths and weaknesses of the conceptual approach just discussed.

Third Horizon (fragmented atlases). Taking into account only a part of this conceptual framework, it would be possible to notice details that escape those who observe the entire theoretical model. For example, a possible horizon of research could focus on one of the five links that we have seen in paragraph 2.2.

Fourth Horizon (sustainability atlas). Other research can be directed to one aspect that is not examined in depth here: an ExO's sustainability. The model in Figure 5 introduces some variables that become relevant in the long term and that help us answer many questions, including the following:

- How long does the organizational growth remain exponential?

- How does the strategy of the ExO change when its market is disrupted by other ExOs?

- In the long run, are all organizations likely to become linear?

For this reason, the fourth horizon ideally encompasses all other possible horizons.

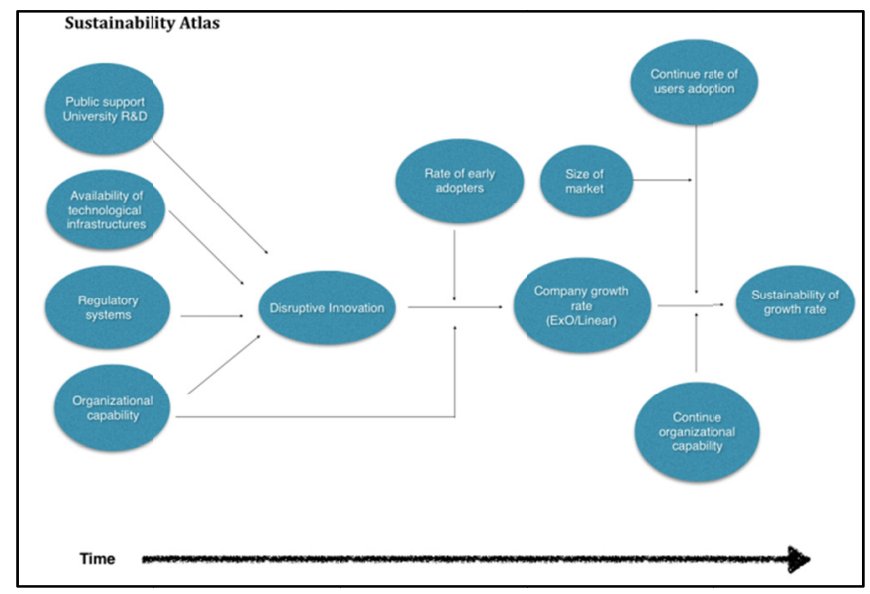

Figure 5. One possible future research horizon could focus on how an ExO changes over time

At this point, this work's theoretical implication should be clear: to propose a conceptual approach to ExOs' complex reality, in order to understand not only the behavior of these organizations, but also the elements that determine their emergence and their impact. In other words, the aim is to bring attention to not only ExOs, but also their surroundings. Based on the evolution of this theoretical approach, future research should also find practical implications. 


\section{Conclusions}

In the coming years, we will hear more and more about Exponential Organizations. Salim Ismail and his colleagues have the credit to have revealed for the first time this theme in a systematic way. The ExOs are very different from the organizations we usually study. All of the following is dramatically different from the reality we know: the way ExOs manage human resources or the processes; the way they face the market; the way they adapt to environmental changes; the way they create new markets and affect the environment; the way they create, obtain and transfer knowledge; the way they use technologies; and the way they have socio-economic impact. The more ExOs differ from traditional organizations, the more organizational studies must to be different from traditional organizational approaches. This is year zero for organizations. Linear organizations will always exist, so the challenge is not to replace the traditional approaches with new ones but to depart from traditional approaches and build new analytical perspectives. I deeply believe that the discipline which studies a certain phenomenon must evolve at the same speed as the phenomenon studied, in order to contribute to the evolution of knowledge about changes affecting our society. Only in this way managerial science will continue being an authentic social science.

The ExO phenomenon's speed is very fast, and our understanding risks falling behind. ExOs are changing the world in an unprecedented way, and future research will represent reflection on not only these new organizations, but also our fate.

\section{References}

Adner, R. (2002). When are technologies disruptive? A demand-based view of the emergence of competition. Strategic Management Journal, 23, 667-688. https://doi-org.proxy.lib.utk.edu/10.1002/smj.246

Aghion P., Bloom N., Blundell R., Griffith R. and Howitt P. (2005). Competition and innovation: an inverted-U relationaship. Quarterly Journal of Economics, 120(2), 701-728. https://doi.org/10.1162/0033553053970214

Allen, J., \& De Grip, A. (2012). Does skill obsolescence increase the risk of employment loss? Applied Economics, 44, 3237-3245. https://doi.org/10.1080/00036846.2011.570727

Aristotle. (1992). Metaphysics (translated by Joe Sachs). Santa Fe: Green Lion Press.

Aschauer, D. A. (1988). Is public expenditure productive? Journal of Monetary Economics, 23, 177-200. https://doi.org/10.1016/0304-3932(89)90047-0

Aschauer, D. A. (1993). Genuine economic returns to infrastructure investment. Policy Studies Journal, 21, 380-390. https://doi.org/10.1111/j.1541-0072.1993.tb01830.x

Audretsch, D. B., \& Stephan, P. (1996). Company-scientist locational linkages: the case of biotechnology. American Economic Review, 86, 641-652. https://doi.org/10.4337/9781786432797.00019

Berman E.M. (1990). The economic impact of industry-funded university R\&D. Research Policy, 19, 349-355. https://doi.org/10.1016/0048-7333(90)90018-2

Bivens, J. (2012). Public Investment. The next "new thing" for powering economic growth. Economic Policy Institute Briefing Paper, \#338, April 18.

Blind, K. (2012). The influence of regulations on innovation: A quantitative assessment for OECD countries. Research Policy, 41(2), 391-400. https://doi.org/10.1016/j.respol.2011.08.008

Bourke, J., \& Crowley, F. (2015). The role of HR; and ICT complementarities in firm innovation: evidence from transition economies. International Journal of Innovation Management, 19(5), 1-25. https://doi.org/10.1142/S1363919615500541

Bower, J. L., \& Christensen, C. M. (1995). Disruptive technologies: catching the wave. Harvard Business Review.

Cao, L., Navare, J., \& Jin, Z. (2018). Business model innovation: how the international retailers rebuild their core business logic in a new host country. International Business Review, 27(3), 543-562. https://doi.org/10.1016/j.ibusrev.2017.10.005

Chesbrough, H. (2001). Assembling the elephant: a review of empirical studies on the impact of technical change unpon incumbent firms. In Burgelman R.A. and Chesbrough H. (Eds.), Comparative studies of technological evolution (pp. 1-36).

Christensen, C. M. (1997). The innovator's dilemma. Harvard Business School Press, Boston, MA. 
Christensen, C. M.. \& Raynor, M. E. (2003). The innovator's solution. Harvard Business Publishing, Boston, MA.

Collis, D. J. (1994). Research note: how valuable are organizational capabilities? Strategic Management Journal, 15, 143-152. https://doi.org/10.1002/smj.4250150910

Danneels, E. (2004). Disruptive technology reconsidered: a critique and research agenda. Journal of Product Innovation Management, 21, 246-258. https://doi.org/10.1111/j.0737-6782.2004.00076.x

Davis, K. E., \& Kruse, M. B. (2007). Taking the measure of law: the case of the Doing Business project. Law \& Social Inquiry, 32(4), 1095-1119. https://doi.org/10.1111/j.1747-4469.2007.00088.x

Dìaz-Chao, À., Sainz-Gonzàlez, J., \& Torrent-Sellens, J. (2015). ICT, innovation, and firm productivity: new evidence from small local firms. Journal of Business Research, 68, 1439-1444. https://doi.org/10.1016/j.jbusres.2015.01.030

Doering, D. S., \& Parayre, R. (2000). Identification and assessment of emerging technologies. In Day G.S., Schoemaker, P. J. H. and Gunther, R. E. (Eds.), Wharton on managing emerging technologies (pp. 75-98). New York.

Dosi, G., Richard, R. R., \& Winter, S. G. (2001). The nature and dynamics of organizational capabilities. Oxford University Press.

Downes, L. (2013). Lessons from Uber: why innovation and regulation don’t mix. Forbes Tech.

Dragoi, A., \& Dumitrescu, G. (2014). Public Policy to support ICT development in Japan. Romanian Economic and Business Review, 9(3), 149-160.

Drori, G. S. (2010). Globalization and technology divides: bifurcation of policy between the "digital divide" and the "innovation divide". Sociological Inquiry, $80(1), \quad 63-91$. https://doi.org/10.1111/j.1475-682X.2009.00316.x

Edwards, P. N., Bowker, G. C., Jackson, S. J., \& Williams, R. (2009). Introduction: an agenda for infrastructure studies. Journal of the Association for Information Systems, Special Issue on e-Infrastructure, 10 (5), $155-173$.

Eisenhardt, K. M., \& Martin, J. A. (2000). Dynamic capabilities: what are they? Strategic Management Journal, 21(10/11), 1105-1121. http://dx.doi.org/10.1002/1097-0266

Endeavor Insight. (2014). If business regulations are so important, why is Silicon Valley successful? Entrepreneurship Ecosystem Insights. $\quad$ Retrieved from $\mathrm{http}$ ://www.ecosysteminsights.org/if-business-regulations-are-so-important-why-is-silicon-valley-successful

Eshima, Y., \& Anderson, B. S. (2017). Firm growth, adaptive capability, and entrepreneurial orientation. Strategic Management Journal, 38(3), 770-779. https://doi.org/10.1002/smj.2532

Etzkowitz, H. (1993). Enterprises from science: the origins of science-based regional economic development. Minerva, 31(3), 326-360. https://doi.org/10.1007/BF01098626

Etzkowitz, H., \& Leydesdorff, L. (1995). The triple helix. University-Industry-Government relations: a laboratory for knowledge based economic development. European Association for the Study of Science and Technology Review, 14(1), 14-19.

Friedman, R. S., \& Deek, F. P. (2003). Innovation and Education in the digital age: reconciling the roles of pedagogy, technology, and the business of learning. IEEE Transactions on Engineering Management, 50(4), 403-412. https://doi.org/10.1109/TEM.2003.819650

Govindarajan, V., \& Kopalle, P. K. (2006). The usefulness of measuring disruptiveness of innovations ex post in making ex ante predictions. Journal of Product Innovation Management, 23, 12-18. https://doi.org/10.1111/j.1540-5885.2005.00176.x

Grant, R. M. (1996). Prospering in dynamically-competitive environments: organizational capability as knowledge integration. Organization Science, 7(4), 375-387. https://doi.org/10.1287/orsc.7.4.375

Gronum, S., Steen, J., \& Verreynne, M. L. (2016). Business model design and innovation: Unlocking the performance benefits of innovation. Australian Journal of Management, 41(3), 585-605. https://doi.org/10.1177/0312896215587315

Guo, C., Jiang, C. X., \& Yang, Q. (2014). The development of organizational capabilities and corporate entrepreneurial processes: the case of Chinese automobile firms. Thunderbird International Business 
Review, 56(6), 483-500. https://doi.org/10.1002/tie.21651

Güttel, W. H., Konlechner, S., Kohlbacher, F., \& Haltmeyer, B. (2009). Strategies against competency obsolescence: the case of R\&D-intensive organizations. International Journal of Human Resources Development and Management, 9(2/3), 124-148. https://doi.org/10.1504/IJHRDM.2009.023449

Hauer, T. (2018). Society and the Second Age of Machine: algorithms versus ethics. Society, 55(2), 100-106. https://doi.org/10.1007/s12115-018-0221-6

Huang, X., \& Sošić, G. (2010). Analysis of industry equilibria in models with sustaining and disruptive technology. European Journal of Operational Research, 207(1), 238-248. https://doi.org/10.1016/j.ejor.2010.04.033

Iacovone, L., Pereira-Lòpez, M., \& Schiffbauer, M. (2017). ICT Use, Competitive Pressure, and Firm Performance in Mexico. World Bank Economic Review, 30, 109-118. https://doi.org/10.1093/wber/lhw023

Ianos, M. G., \& Oproiu, G. C. (2018). Using technology to teach Chemistry. A theoretical approach. eLearning \& Software for Education, 3, 55-62.

Ismail, S. (2013). Exponential Organizations. Why new organizations are ten times better, faster and cheaper than yours (and what to do about it). Diversion Books, New York.

James J. (2002). The digital divide between Nations as international technological dualism. International Journal of Development Issues, 1(2), 25-40.

Jansen, C., \& Jeschke, S. (2018). Mitigating risk of digitalization through managed industrial security services. AI \& Society, 33(2), 163-173. https://doi.org/10.1007/s00146-018-0812-1

Kahn, K. B. (2018). Understanding innovation. Business Horizons, 61(3), 453-460. https://doi.org/10.1016/j.bushor.2018.01.011

Kallis, G. (2017). Radical dematerialization and degrowth. Philosophical Transactions of the Royal Society A: Mathematical, Physical \& Engineering Sceinces, 375(2095), 1-13. https://doi.org/10.1098/rsta.2016.0383

Kaufman, H. (1974). Obsolescence and professional career development. AMACON, New York.

King, A. A., \& Baatartogtokh, B. (2015). How useful is the theory of disruptive innovation? MIT Sloan Management Review, 57(1), 77-90.

Kurzweil, R. (2001). The law of accelerating returns. Retrieved from http://www.kurzweilai.net/the-law-of-accelerating-returns

Lepore, J. (2014). The disruption machine: what the gospel of innovation gets wrong. New Yorker, June 23.

Levine, S. (2015). The Powerhouse; Inside the Invention of a Battery to Save the World. Viking, New York.

Lewrick, M., Raeside, R., \& Omar, M. (2012). Organizational capabilities for successful innovation. Proceedings of the 18th International Conference on Engineering, Technology and Innovation.

Liang, X., \& Liu, A. M. M. (2018). The evolution of governement sponsored collaboration network and its impact on innovation: a bibliometric analysis in the Chinese solar PV sector. Research Policy, 47(7), 1295-1308. https://doi.org/10.1016/j.respol.2018.04.012

Lun, Y. H. V., Shang, K., Lai, K., \& Cheng, T. C. E. (2016). Examining the influence of organizational capability in innovative business operations and the mediation of profitability on customer satisfaction: an application in intermodal transport operators in Taiwan. International Journal of Production Economics, 171(part 2), 179-188. https://doi.org/10.1016/j.ijpe.2015.02.019

Markovich, S. J. (2012). Promoting Innovation Through R\&D. Council on Foreign Relations website, Retrieved from http://www.cfr.org/innovation/promoting-innovation-through-rd/p29403

Mazzucato M. (2013). The Entrepreneurial State: Debunking Public vs. Private Sector Myth. London: Anthem Press.

Mazzucato, M. (2015). The innovative state. Governments should make markets, not just fix them. Schumpeter's Heirs.

McMillan, G. S., \& Hamilton III, R. D. (2003). The impact of publicly funded basic research: An integrative extension of Martin and Salter. Ieee Transactions on Engineering Management, 5(2), 184-191. https://doi.org/10.1109/TEM.2003.810829

McMillan, G. S., Narin, F., \& Deeds, D. L. (2000). An analysis of the critical role of public science in innovation: 
the case of biotechnology. Research Policy, 29(1), 1-8. https://doi.org/10.1016/S0048-7333(99)00030-X

Messaoud, B., \& Teheni, Z. E. G. (2014). Business regulations and economic growth: what can be explained? International Strategic Management Review, 2(2), 69-78. https://doi.org/10.1016/j.ism.2014.03.001

Morone, J. (1989). Strategic use of technology. California Management Review, 31(4), 91-110. https://doi.org/10.2307/41166584

Morrison, C. J., \& Schwartz, A. E. (1996). State infrastructure and productive performance. American Economic Review, 86(5), 1095-1111.

Mykolayivna, S., \& Sergiyovych, G. O. (2015). Formation of ecology and economic mechanism of dematerialization at the enterprise. Marketing \& Management of Innovations, 2, 258-266.

Narin, F., Hamilton, K. S., \& Olivastro, D. (1997). The increasing linkage between U.S. technology and public science. Research Policy, 26(3), 317-330. https://doi.org/10.1016/S0048-7333(97)00013-9

Penrose, E. (1959). The Theory of the Growth of the Firm. London: Basil Blackwell.

Philipson, S. (2016). Radical innovation of a business model. Competitiveness Review, 26(2), 132-146. https://doi.org/10.1108/CR-06-2015-0061

Prahalad, C. K., \& Hamel, G. (1990). The core competence of the corporation. Harvard Business Review, 68(3), 79-91.

Rahman H. A. (2017). An exchange Theory of Relationship in online labor markets. Academy of Management Annual Meeting Proceedings, 1, 1. https://doi.org/10.5465/AMBPP.2017.17785abstract

Rosenberg, N., \& Birdzell, L. E. Jr. (1990). Science, technology and western miracle. Scientific American, 263(5), 42-54. https://doi.org/10.1038/scientificamerican1190-42

Salandra, R. (2018). Knowledge dissemination in clinical trials: exploring influences of institutional support and type of innovation on selective reporting. Research Policy, 47(7), 1215-1228.DOI: https://doi.org/10.1016/j.respol.2018.04.005

Salter, A. J., \& Martin, B. R. (2001). The economic benefits of publicly funded basic research: A critical review. Research Policy, 30(3), 509-532. https://doi.org/10.1016/S0048-7333(00)00091-3

Sinitsyn, M. (2018). Choosing the quality of the fit between complementary products. Journal of Economics and Management Strategy, 25(1), 161-178. https://doi.org/10.1111/jems.12136

Spieth, P., Schneckenberg, D., \& Matzler, K. (2016). Exploring the linkage between business model (\&) innovation and the strategy of the firm. $R \& D$ Management, 46(3), 403-413. https://doi.org/0.1111/radm.12218

Stephan, A., Schmidt, T. S., Bening, C., \& Hoffmann, V. H. (2017). The sectoral configuration of technological innovation systems: patterns of knowledge development and diffusion in the lithium-ion battery technology in Japan. Research Policy, 46(4), 709-723. https://doi.org/10.1016/j.respol.2017.01.009

Toole, A. A. (2012). The impact of public basic research on industrial innovation: evidence from the pharmaceutical industry. Research Policy, 41(1), 1-12. https://doi.org/10.1016/j.respol.2011.06.004

Van Der Meer, A., \& Van Winden, W. (2003). E-governance in cities: A comparison of urban information and communication technology policies. Regional Studies, 37(4), 407-419. https://doi.org/10.1080/0034340032000074433

Wessel, M., \& Christensen, C. M. (2012). Surviving disruption. Harvard Business Review.

World Bank. (2004). Doing Business in 2004: understanding regulation. World Bank, Washington, DC.

Wylie, P. J. (1996). Infrastructure and Canadian economic growth 1946-1991. The Canadian Journal of Economics, 29, 350-355. https://doi.org/10.2307/136015

Yu, D., \& Hang, C.C. (2010). A reflective review of disruptive innovation theory. International Journal of Management Reviews, 12(4), 435-452. https://doi.org/10.1111/j.1468-2370.2009.00272.x

Yunis, M., Tarhini, A., \& Kassar, A. (2018). The role of ICT and innovation in enhancing organizational performance: The catalysing effect of corporate entrepreneurship. Journal of Business Research, 88, 344-256. https://doi.org/10.1016/j.jbusres.2017.12.030

Zhang, F., \& Li, D. (2018). Regional ICT access and entrepreneurship: Evidence from China. Information and Management, 55(2), 188-198. https://doi.org/10.1016/j.im.2017.05.005 


\section{Notes}

Note 1. Oxford Dictionary

Note 2. http://singularityu.org/

Note 3. Source: businessdictionary.com

Note 4. Source: www.whitehouse.com

Note 5. Online article Retrieved from

http://www.ecosysteminsights.org/if-business-regulations-are-so-important-why-is-silicon-valley-successful/

Note 6. Retrieved from

http://www.privco.com/privcos-the-top-10-cities-of-the-year-for-private-tech-acquisitions-1-silicon-valley-sf-2-n yc-3-san-diego-4-chicago-5-seattle

Note 6. Retrieved from https://www.uschamberfoundation.org/regulatory-climate-index-2014-section-i

\section{Copyrights}

Copyright for this article is retained by the author(s), with first publication rights granted to the journal.

This is an open-access article distributed under the terms and conditions of the Creative Commons Attribution license (http://creativecommons.org/licenses/by/4.0/). 